\title{
Economics During the Pandemic: U.S. vs. China
}

\author{
Name: Yukai Zhang ${ }^{1, a}$
}

\author{
${ }^{1}$ University of Miami \\ ${ }^{a}$ Email Address: yxz1624@miami.edu
}

\begin{abstract}
At the end of 2019, COVID-19 outbroke that had a crucial impact on global economics. Containment is slowly becoming the antithesis of economic development. To study what aspects of our economy have been affected by the COVID-19 outbreak, and how to analyze and try to study and solve these problems from an economic perspective. This is the goal of this paper.

Methods: By analyzing the supply and demand sides, unemployment rate and macro policy of the two countries, the Chinese and American economies under the epidemic were explored. To analyze their influence and to figure out future economic trends.

Conclusion: The epidemic has greatly impacted the supply and demand market of the global industrial chain. Slack in global trade and production has led to a sharp rise in unemployment. There are a lot of structural risks for both the Chinese and American economies. Through fiscal stimulus, we will stabilize employment, accelerate recovery and seek new growth. China and the United States are slowly emerging from the mire of the epidemic.
\end{abstract}

Keywords: COVID, Supply-side shocks, Demand shocks, labormarket, CPI, PPI, GDPInflation, Unemployment Rate, Treasury, Interest rate.

\section{INTRODUCTION}

Since COVID-19 reared its ugly head in Wuhan, China in December 2019, it soon spread all over the nation along trains and flights during Spring Festival travel rush in the following January. In March 2020, it already swept through scores of countries around the world and escalated into a global health event, which was defined by the World Health Organization as a public health emergency of international concern, or a PHEIC in short. To contain the epidemic, China officially issued a range of measures including mobility restrictions, quarantines, and work-from-home policies. Though effective in curbing the spread of the epidemic, these measures cast a blight on economic growth, with realeconomy entities taking the full force: keeping factories and workers idle for two months has led many small- and medium-sized enterprises (SMEs) to the brink of bankruptcy. According to the National Bureau of Statistics, in the first quarter of 2020, China's GDP dropped by $6.8 \%$ year on year. By early May 2020, the epidemic in China had been initially brought under control, and enterprises in many places were resuming work and production in an orderly manner to varying degrees. With the introduction of the new coronavirus vaccine in the United States in 2021, the epidemic in the
U.S. has been under increasing control with a gradual increase in the vaccination rate. However, in the closelyknit network of global economic integration, it is difficult for China and the United States to recover in the short term. In addition, as the global epidemic is getting worse, and the epidemic will still have a lasting impact on these two economies. As reported by the Chinese authorities, $3,253,457$ people have died, and the number is increasing by 10,000 per day. It has also hit the economy hard. Numerous SMEs have gone bankrupt due to the disruption of global trade, the ailing tourism industry, the blockade of cities and so on. Thousands of people went unemployed. As shown by the data from UK Finance on May 1, 2021 (cn.investing.com), China's unemployment rate reached 6.2 percent in March 2020, while the U.S. saw an employment rate over 14 percent in April. Global GDP has also taken an unprecedented hit. According to the "Global Economic Outlook Report" released by the Organization for World Economic Cooperation (OECD), the world GDP would decline by $4.2 \%$ in 2020 , a huge blow to the global economy. The COVID-19 was unarguably the biggest economic event to hit the world since the subprime mortgage crisis in 2007. Since 2020, the US stock market has triggered the circuit breaker three times, the Chinese counterpart also witnessed a decline, leading the governments to quantitative easing. 
Now the interest rate of national debt of these two countries has risen in the post-epidemic era, and the stock market has been pulled back on a large scale. There are a lot of economic mechanics in these stages, accompanied by the undercurrents of rivalry between the great powers. An in-depth probe into the economic dynamics of these two countries amid the pandemic can help us understand the global economic situation and allow us to predict the economic development after the epidemic. The present work intends to analyze and forecast the economic development of China and the U.S. with regards to the supply-demand relation, the unemployment rate, and their respective fiscal and monetary policies.

\section{SUPPLY-SIDE SHOCKS}

On the supply side, SMEs in the upper reaches of the industry, hit the hardest by the Covid-19 pandemic, are struggling to survive. Policies to help these enterprises are particularly important. Despite the reduction of production costs and favorable governmental policies, these businesses still face an uphill battle to recover their production capacity, and the recovery is largely dependent on how the pandemic develops. To look on the bright side, however, the pandemic also helped to cut overcapacity and hence phased out enterprises that contributed little to the national economy. In terms of the industrial makeup, the primary industry suffered less than other industries amid the pandemic, but the price of imported and exported food showed tangible fluctuations. The secondary industry is undoubtedly the worst affected sector, with the global supply chain considerably disrupted. China has performed well in this respect. Thanks to its investments into medium- and low-end industrial entities since the 1980s, China has built a strong and resilient industrial chain. This will allow China to quickly popularize the vaccines and open its doors to the world, hence gaining a competitive edge among the global powers when the pandemic comes to an end. India and Southeast Asia that used to be rivals to China are still in a quagmire. The unmatched market opportunities and favorable economic environment in China will undoubtedly attract a large number of investments. This is also a valuable opportunity for the United States, which leads the world in the rate of vaccination, to resume the manufacturing industry, create more jobs and reduce the rate of unemployment. The tertiary industry has benefited the most from the pandemic, as the Internet has become the main channel for work and recreation amid lockdowns. This trend is most pronounced in the stock market as the stock prices of enterprises in this sector soars. However, this has also resulted in the excessive value of the industry. With the change in the monetary policy and the slow recovery of traditional industries, some stock prices in the tertiary industry will certainly witness a return to the prepandemic level. Nevertheless, in the long term, the tertiary industry remains a promising sector.

\section{DEMAND SHOCKS}

China and the U.S. show a similar trend on the demand side of economy, according to CEIC's private consumption data. People are generally not satisfied with their income, short of confidence in the market or incentive to consume, with their enthusiasm for consumption largely dampened. As with the breakout of SARS in 2003 that gave rise to online shopping, the Covid-19 pandemic boosted the Internet industry. A technology or service, when we grow overly dependent on it, becomes infrastructure. Thus, in the future, such technologies and services as big data, cloud services, artificial intelligence and unmanned services will continue to prosper and play a dominating role in the world. The impact of the pandemic on the tertiary sector lasts shorter in that the demand elasticity coefficient of this sector is small. As people's demand for such goods or services remains, plus various consumption stimulus policies issued by the government, the tertiary industry will quickly recover after the pandemic. In comparison, the pandemic will have a longer impact on the secondary industry. Despite the stimulating policies the government issues and the demand that remains, consumers will delay consumption due to lack of confidence in the market. A fine example is that the pandemic has reduced the domestic demand for clothing, putting the clothing industry at stake and resulting in a domino effect that leads the textile industry and then the textile machinery to predicaments. The domino in the secondary industry works slower than in the tertiary industry, and hence the secondary industry is estimated to come back to life next year.

The economy suffered greatly from the pandemic, with frustrated desire for consumption and reduced consumer demand. This is especially true in China, where government subsidies are not directly available as in the U.S. Nonetheless, regional governments have issued a range of bills for fiscal stimuli to shore up consumer demand. In mid-2020, China successfully controlled the epidemic, with the consumption side coming to an inflection point and a V-shaped rebound. Overall, with the gradual spread of vaccines in the US, the gradual control of the pandemic, plus the low base effect in 2020, China and the US are expected to see a V-shaped rebound in consumption growth in 2021. The UK has provided statistics as to the changes in CPI and PPI in China and the US. Firstly, the US was healthier in terms of PPI and CPI, both of which were growing at a healthy rate when the virus broke out. Secondly, there are two reasons for the decline or even negative growth of CPI in China. The first and foremost reason is that the price of pork has been reasonably controlled and gradually dropped. The second factor is the insufficient driving force of consumption. Both China and the US saw a growing PPI in late 2020 and early 2021, reaching about $4 \%$ now. In contrast, China's index has shown a downward trend. This reflects 
two economic problems. First, as the nation contains and recovers from the pandemic, a large amount of liquidity has been released, causing the inclusive cost of raw materials to increase, and there has been a certain amount of importing inflation in the production industry. Second, the supply-demand conduction is insufficient. The rise of raw materials should have increased the price of commodities, but the overall CPI showed a definite downward trend. This will lead to a buyer's market in which supply exceeds demand. Nonetheless, overall, CPI and PPI indicators in both countries are moving in a healthy direction.

\section{IMPACT ON THE LABOR MARKET}

According to CN.investing.com on May 1, 2021, China's unemployment rate rose to 6.7 percent by the start of the epidemic, while the US unemployment rate rose to more than 14 percent. As mentioned before, China witnessed mass closure of SMEs in the pandemic, but where did all the unemployed workers go? The truth of China's unemployment rate is highly questionable. According to China's official statistics, 50 million migrant workers lost their urban jobs as a result of closures in March 2020 alone, but the government thinks they can continue to farm in the countryside as farmers instead of working in cities. This is a very considerable ambiguity. Unemployment may have been as high as 20 percent, according to estimates by the macroeconomic analysis team of China and Thailand Securities. According to a recently published research paper titled "The US Labor Market during The Beginning of The Pandemic Recession," and a research paper by a member of The Chinese Academy of Sciences, characteristics of unemployment mentioned in the article can also be widely applied to the world. In China, due to a larger population base, relatively ambiguous definition of unemployment, and different time and scope of impact of the epidemic from that of the US, it may be difficult to mine data of real unemployment. From a logical perspective, the major characteristics should be basically consistent. Overall, from February to May 2020, the percentage of employees in small business was higher, and people with lower incomes were more likely to lose their jobs during the epidemic. In general, this is a shared feature of unemployment in China and the US. SMEs are less likely to withstand a downturn, while large firms have stronger capital chains. Large enterprises see a considerably smaller unemployment rate than their smaller counterparts. second, the highest unemployment rate is in the entertainment and services sectors, which have been hit the hardest by the pandemic. Third, the lowest income group is more likely to earn, and some labor-intensive industries have been particularly hard hit by local transport restrictions and disruption of international supply chains. Fourth, the company's operational layoffs are higher than the passive layoffs. To avoid the risk of bankruptcy, companies have to axe more employees and reduce the production cost. Massive layoffs, however, triggered a plethora of problems, and in response, Chinese government released a range of administrative policies, such as restricting layoffs, extending enrolment to state-owned enterprises, providing new job opportunities, encouraging gig economy, and launching new infrastructure projects to absorb thousands of construction workers. All these policies are aimed to create new jobs and shorten the time for finding employment. Nonetheless, it will certainly put some strain on China's finance. On the part of the US, the focus was put on the distribution of benefits, to reduce the impact of business on the economy, promote consumption and improve the liquidity of capital. One downside of this, however, is that it increases the natural rate of unemployment, because people are more likely to get money when they are out of work.

\section{MONETARY AND FISCAL POLICY RESPONSES}

As the pandemic escalated, the global supply chain was greatly challenged, the unemployment rate in the US and China soared for a time, and the economy was in a state of stagnation. China and the US printed more money and the global economy unleashed a flood of water. We often believe that printing a lot of money will result in a rapid inflation, but it does not need to be that way. However, the CPI and GDP inflation measures in the US have not risen more than 2 percent. First, because the US dollar is the common currency of the world, the additional issuance of US dollars will create a huge inflationary pressure on other countries. Because of its strong economic strength and the credit on dollars, the US can pass on the inflationary pressure to other countries to boost its own economy. Second, liquidity becomes a crucial indicator. At a time when global trade was severely disrupted, it became a wise option to print more money around the world to boost liquidity. However, the increased money supply in the economic downturn flows into the financial market instead of directly to the real industry, resulting in financial idling. This also explains the large increase of the Chinese and US stock markets in 2020 , but the actual inflation rate did not rise substantially. As we move into 2021, there is growing optimism about economic recovery. China first adjusted a series of pecuniary and administrative policies, such as stabilizing the stock market and housing prices to prevent monetary bubbles. China's epidemic management is relatively milder than the US, and a large number of industries have returned to production. Nevertheless, countries like India and those in Southeast Asia, which also rely on low-end manufacturing as China does, are still in the mire of COVID-19. The money that the US creates goes around the world through global trade settlement, but the goods that China produces are sold back to the US, resulting in imported inflation. In early 2021, the US responded with a series of policies aimed at reviving the economy. Biden 
passed a $\$ 1.9$ trillion stimulus bill, while interest rates on U.S. debt rose and flowed back into the dollar. Whether this is a precursor to higher interest rates and tighter money supply in the US will need to be further analyzed by other indicators, but it is clear that quantitative easing has helped the US and China get through some of the crises without causing massive inflation.

According to data from UKFI, Treasury rates have been falling sharply since March of 2020, and 10-year yields have been rising since late July last year. In contrast, the interest rate on Chinese government bonds has risen from 2.51 percent to 3.287 percent since the end of May last year and is now close to 4 percent. The rising interest rate of Chinese government bonds coincides with the inflection point of China's efforts to basically control the epidemic. From this we can see that Treasury interest rates have risen in part due to the hope that the situation will improve. The ten-year Treasury yield in the US is a very important indicator of global financial markets and it is a very significant measure of all asset prices. Generally speaking, a rise in the interest rate on Treasury bonds will be accompanied by a rise in the domestic interest rate. However, interest rates in the US are still at zero, but the yield on the ten-year Treasury bond continues to rise. This actually indicates that the rise of US Treasury yields has an "antecedent" effect, which in essence equals to raising interest rates. This implies the US government's desire to slowly end its quantitative easing policy to combat upward inflationary pressure. There was an exception: a rise in China's ten-year bond yields at the end of May last year indirectly influenced the direction of U.S. Treasury yields. As China gradually controls the epidemic, it is gradually tightening the money supply, which implicitly puts budgetary pressure on the US to raise interest rates. Partly, this has influenced some flows from the US into the Chinese government bond market, which has pushed up the remaining indices and indirectly put a downward pressure on the dollar index. It has also been instrumental in the increased risk of imported inflation in the US. That is one of the reasons why America raised ten-year Treasury yields in July. Biden's \$1.9 trillion stimulus bill looks more like an inflection point in U.S. monetary policy. The problem of slowly deflating the bubble in the US financial market while preventing the risk of a bubble bursting is one that both China and the US will face. Then, effective epidemic control has played an important role. With the continuous promotion of vaccines in the US, the global economy is likely to recover soon. In general, there is a lot of economics and power game going on. Either approach, the two countries share a common vision for global economic recovery and containment of the pandemic.

\section{CONCLUSION}

Time after time we tend to classify inflation indicators into inflation or deflation, but controversies remain in this regard. In my view, inflation and deflation are inevitable in an economic cycle. Among them, CPI, PPI and the financial market are not isolated indicators; rather, they echo federal monetary policies. Both the US and China have their own models of monetary policy to help minimize their losses. The pandemic is undoubtedly an external economic shock, but it is not an institutionalized crisis compared with the subprime mortgage crisis in 2008. I believe we will see much economic improvement in mid- or late-2021. China and the US share a national policy of stabilizing employment, stimulating demand, preparing to open the door, supporting companies in the secondary industry, and developing the tertiary industry to strengthen the economic drive. After the end of the pandemic, the competition between China and the US will grow, especially in the high-tech industry, a crucial area for economic growth. Nevertheless, in terms of international trade, China and the US have a lot to win. Under the policy of unlimited quantitative easing, the US has put more pressure on China, and the priority is to remove the economic bubble in some Chinese industries. Chinese Premier Zhou once said: "Seek common ground while reserving differences." Competing aggressively in industries where we need to compete and working together in areas where collaboration is necessary can undoubtedly lead the two economies to a win-win scenario.

\section{REFERENCES}

[1] Zeping Ren, Analysis of the Impact of the Epidemic on China's Economy and Policy Suggestions(2020), in: National Knowledge Infrastructure, NKI.

[2] Xu Qiyuan, How to view China's economy under the impact of the epidemic -Xuqiyuan, in: National Knowledge Infrastructure, NKI.

[3] Investing Data: [Online Availiable] at: Investing.com [4] Eastmoney: [Online Availiable] at :Eastmoney.com

[5]Ceidata: [Online available] at: https://www.ceicdata.com/zh-hans/indicator/unitedstates/private-consumption-expenditure

[6] Wang Jixiang The strength and weakness of China's manufacturing supply chain. (2020), in: National Knowledge Infrastructure, NKI.

[7] Li Xia The Impact of COVID-19 on the World and China's Macro Economy in 2020 (2020), in: National Knowledge Infrastructure, NKI.

[8] Tomaz Cajner, Leland D. Crane, Ryan A. Decker, John Grigsby, Adrian Hammins-Puertolas, Erik Hurst, Christopher Kurz and Ahu Yildirmaz, The US Labor Market during The Beginning of The Pandemic Recession (May 2020), in: National Bureau of Economic Research.

[9] Zhi Yan, The Impact of COVID-19 on China's Economy and Reflections (2020), in: National Knowledge Infrastructure, NKI. 